\title{
Preface for the SUITMA10 Conference proceedings Soils of Urban, Industrial, Traffic, Mining, and Military Areas (SUITMAs) are essential resources that deserve our attention for the sustainable management of anthropized environments
}

\author{
K-H. J. Kim ${ }^{1}$ • J. L. Morel $^{2}$ - T. Nehls ${ }^{3}$ P. Charzynski ${ }^{4} \cdot$ M. J. Levin ${ }^{5} \cdot$ V. I. Vasenev ${ }^{6}$ \\ Received: 9 March 2021 / Accepted: 10 March 2021 / Published online: 5 April 2021 \\ (C) The Author(s), under exclusive licence to Springer-Verlag GmbH Germany, part of Springer Nature 2021
}

The soils of heavily anthropized areas are underestimated resources for the sustainable management of areas occupied by humans. They are involved in the provision of a wide range of ecosystem services (Morel et al. 2015). They may be slightly or completely different from natural soils and may exhibit specific characteristics that make them scientific subjects in themselves in the soil science community.

Despite their great diversity, they have been grouped together under the acronym SUITMA, that is to say soils in urban, industrial, traffic, mining, and military areas. This acronym also defines a group of scientists and actors who consider that any soil under human influence is of major importance for general knowledge and for the management of human communities. This group, created in 1998 within the framework of the International Union of Soil Sciences (Burghardt et al. 2015), meets every 2 years to share the knowledge acquired and define questions for the future.

The SUITMA group has been very active during the first 20 years of the twenty-first century, and has contributed to a better understanding of the properties, functioning, impacts, and long-term evolution of soils from major human influences, including the provision of ecosystem services in

K-H. J. Kim

johnkim@uos.ac.kr

1 The University of Seoul, Seoul, Republic of Korea

2 Université de Lorraine, INRAE, Nancy, France

3 Technische Universitaet Berlin, Berlin, Germany

4 Nicolaus Copernicus University, Torun, Poland

5 University of Maryland, College Park, MD, USA

6 RUDN University, Moscow, Russia anthropized environments, a subject addressed during the SUITMA9 Conference in 2019 (Vasenev et al. 2019).

"SUITMA+20" was the theme of the 10th SUITMA Conference aiming to look back 20 years of the past and look forward another 20 years to come, which took place from June 16 to 21, 2019, in Seoul, the historic capital of Korea for over 600 years. One hundred and sixty-five soil scientists from 20 countries participated. Sixty-nine oral and 88 poster presentations were made during this conference. The conference was organized with seven scientific sessions and technical visits as well as great moments of conviviality.

Following previous SUITMA conferences which published selected papers in special issues of the Journal of Soils and Sediments, a new series of twenty papers was selected and published in this special issue of SUITMA10. These papers reflect several main and essential questions related to SUITMAs: (i) Contamination of anthropized areas is still a problem that affects many countries around the world, not only those generated by mining and industrial activities but also those resulting from new technologies and new materials, the most common of which are plastics (Choi et al. 2020). (ii) Being able to map urban soils is always a challenge, and new knowledge is needed to continue the remarkable work that has been done especially in large US cities (e.g., New York), with the definition of instrument assessment of soil quality, as well as appropriate classification strategies and systems. (iii) Providing information on the role of urban soils in major cycles is of the utmost importance in order to further strengthen knowledge on the capacity of SUITMAs to store elements of vital importance for humanity and the environment (e.g., C and P). (iv) SUITMAs also remain a very relevant tool for archeologists who, together with soil scientists, provide information on human history. (v) Managing SUITMAs to, for example, provide better living conditions in urban areas, also means being able to design and develop functional soils that 
can provide high level ecosystem services; green roofs and built floors are examples of the soils created by humans for humans and biodiversity (Sněhota et al. 2020).

Each of the twenty papers is a contribution to these issues and opens new knowledge and new ways to sustainably manage the anthropized environments.

Acknowledgements As guest editors, we would like to express our gratitude to the authors for their presentations at the conference and for their contribution to this issue and more generally to the understanding of the complex processes that occur in urban environments.

\section{References}

Burghardt W, Morel JL, Zhang G-L (2015) Development of the soil research about urban, industrial, traffic, mining and military areas (SUITMA). Soil Sci Plant Nutr 61:3-21
Choi YR, Kim YN, Yoon JH, Dickinson N, Kim KH (2020) Plastic contamination of forest, urban, and agricultural soils: a case study of Yeoju City in the Republic of Korea. J Soils Sediments (this issue). https://doi.org/10.1007/s11368-020-02759-0

Morel JL, Chenu C, Lorenz K (2015) Ecosystem services provided by soils of urban, industrial, traffic, mining, and military areas (SUITMAs). J Soils Sediments 15(8):1659-1666

Sněhota M, Hanzlíková J, Sobotková M, Moravcik P (2020) Water and thermal regime of extensive green roof test beds planted with sedum cuttings and sedum carpets. J Soils Sediments (this issue). https:// doi.org/10.1007/s11368-020-02778-x

Vasenev VI, Morel JL, Nehls T, Shaw RK, Kim KJ, Hajiaghayeva RA (2019) Challenges and opportunities of urbanization for soil functions and ecosystem services. J Soils Sediments 19:3123-3126. https://doi.org/10.1007/s11368-019-02389-1

Publisher's note Springer Nature remains neutral with regard to jurisdictional claims in published maps and institutional affiliations. 